\title{
Analysis of Environmental Physical-Chemical Factors and Macroalga Species in The Coastal Water of Nusalaut, Central Maluku - Indonesia
}

\author{
Karel Melsasail ${ }^{1,2}$, Ali Awan ${ }^{3, *}$, Pamella M. Papilaya ${ }^{3}$ \\ ${ }^{1}$ Biology Education Study Program, College of Teacher Training and Education Science- \\ Gotong Royong, Masohi, Indonesia. Raya Masohi Street, Masohi, Indonesia \\ ${ }^{2}$ Postgraduate Biology Education Study Program, Pattimura University, \\ Jl. Dr. Tamaela, Ambon 97116 \\ ${ }^{3}$ Biology Education Study Program, Faculty of Teacher Training and Education Science, Pattimura University, Jl. Ir. M. Putuhena, \\ Ambon 97233.
}

\begin{abstract}
The physical-chemical factors of environment are very influential on the presence and the growth of macrolaga in waters. Well-maintained water habitat is a good environment for the growth of macroalgae. A research has been conducted on the physicochemical environmental factors and the macroalgae species in the coastal waters of Nusalaut Island using transect method, and it was a survey research on four different observation stations. The results of the research showed that station I (Amet Village) has the best physicochemical factors for the presence and the growth of macroalgae, compared to station II (Nalahia Village), station III (Sila Village) and station IV (Leinitu Village). The most widely found macro algae are from the Rhodophyta class, with a total of 17 species of macroalgae, of which 15 species are found in station I.
\end{abstract}

Keywords: Macroalga, environmental factors, the coastal water of Nusalaut

\begin{abstract}
Abstrak (Indonesian)
Faktor fisik kimia lingkungan sangat berpengaruh terhadap kehadiran dan pertumbuhan makrolaga pada suatu perairan. Habitat perairan yang terjaga menjadi lingkungan yang baik bagi pertumbuhan makroalga. Telah dilakukan penelitian tentang faktor fisik kimia lingkungan dan jenis-jenis makroalga di perairan Pantai Pulau Nusalaut dengan menggunakan metode transek, dan merupakan penelitian survey pada empat stasiun pengamatan yang berbeda. Hasil penelitian menunjukkan bahwa stasiun I (Desa Amet) memiliki faktor fisik kimia terbaik bagi kehadiran dan pertumbuhan makroalga bila diabandingkan dengan stasiun II (Desa Nalahia), stasiun III (Desa Sila) dan stasiun IV (Desa Leinitu). Makroalga yang paling banyak ditemukan berasal dari kelas Rhodophyta, dengan total makroalga yaitu sebanyak 17 spesies, dimana 15 spesies diantaranya ditemukan pada satasiun I.
\end{abstract}

Kata kunci: Makroalga, faktor lingkungan, perairan pantai Nusalaut

\section{Introduction}

The well-maintained coastal water habitat from the interference of the external environment makes a lot of species of marine organisms able to live sustainably in the ecosystem balance including macroalgae, chlorophyll and pigmented plants whose roots, stems and leaves cannot be distinguished, which are so-called as thallus plant [1]. The diversity of macroalgae species in a waters can be an indicator of water quality. According to Fachrul [2] and Namakule [3], if the diversity of macroalgae species in a waters is high, the quality of the waters will be good, whereas if the diversity of macroalgae species in a waters is low, the quality of the waters has decreased.

Article History:

Received: 30 November 2017

Accepteed: 16 February 2018

DOI: $10.22135 /$ sje.2018.3.1.31-36

*Corresponding Author: aliawan1966@gmail.com
The presence of macroalgae in a waters is determined by physical and chemical factors in these waters. Anggadireja [4] states that the growth and distribution of macroalgae are strongly influenced by the physiological tolerance of the biota towards environmental conditions, including the physical and chemical factors. Physical factors are such as temperature, turbidity and strenth of seawater currents, while chemical factors are such as salinity, degree of acidity $(\mathrm{pH})$, and dissolved oxygen (DO) greatly affect the life of aquatic organisms $[5,6]$

The optimal temperature for macrolagae growth varies depending on the speceis and the latitude where the macroalgae is located [7]. The strength of currents is important for the diffusion process of gases and ions in water that affects the growth of macroalgae in terms of the nutrient availability [8]. High turbidity can inhibit the penetration of light into the water, so that it can affect the process of assimilation of macroalgae [9]. Changing salinity will lead to low diversity of macroalgae species in certain waters [10]. Macroalgae requires water that tends to be alkaline, so that the $\mathrm{pH}$ of water strongly determines the presence of macroalgae. The dissolved oxygen in waters is very influential to the photosynthesis process of macroalgae. Thus, dissolved oxygen becomes one of the determinants for macroalgae growth. Therefore, waters with good 
environmental factors are always followed by a large macroalgae coverage distribution.

Nusalaut Island is one of the islands located in Central Maluku district, Maluku province, with an area of $32.50 \mathrm{~km}^{2}$ and a coastline of $25.925 \mathrm{~km}$ [11]. Administratively, Nusalaut Island is divided into 7 villages: Abubu, Akoon, Amet, Nalahia, Sila, and Leinitu. According to Papalia and Arafah [12], studies have found that as many as 36 species of macroalgae are present in Nusalaut waters, but their presence is threatened by anthropogenic activity such as excessive exploitation of sand and stone, unfriendly fishing practices, throwing out garbages in sea, and shipping activities that potentially cause pollution. All of these things in the long term will affect the physicochemical factors in Nusalaut waters that directly affect the macroalgae species in these waters. Therefore, research has been done on the analysis of physicochemical environmental factors on the diversity of macroalgae in the coastal waters of Nusalaut Island, Central Maluku District.

\section{Experimental Section}

This research is a survey research with transect method to reveal the condition of physicochemical factors on the diversity of macroalgae in coastal waters of Nusalaut of Central Maluku district. The samples were collected using purposive sampling technique at four different stations, namely station I Amet village, station II Nalahia village, station III Sila village III, and station IV Leinitu village.

\subsection{Determination of Data Collection Location}

The location of the data collection was determined by taking into account the habitat of macroalgae. In each station were made 5 vertical transects which were placed perpendicular to the coastline starting from the highest tide limit to the sea with a transect length of $100 \mathrm{~m}$ and the distance between transects $25 \mathrm{~m}$. At every $5 \mathrm{~m}$ from the highest tide limit of each transect was placed an observation plot with a size of $1 \times 1 \mathrm{~m}$ and side $25 \times 25 \mathrm{~cm}$ as many as 22 observation plots.

\subsection{Data Collection of Environmental Physical Factors}

The data collection of the environmental physical factors includes sea water temperature, strength of ocean currents, and turbidity of seawater. The temperature of the seawater was measured using a thermometer dipped to $3 / 4$ the length of the thermometer into the water,left alone until the scale pointer did not move, and the result was recorded. The current strength was measured using a current bulb placed at the water location. A stopwatch was used to measure the time until the strap on the current ball became tight, and the compass was used to determine the direction of the current. The results obtained were then calculated by the formula $\mathrm{V}=\mathrm{S} / \mathrm{T}$, in which $\mathrm{V}$ was the current velocity $(\mathrm{cm} / \mathrm{s}), \mathrm{S}$ was the length of the rope, and $\mathrm{T}$ was the time until the strap was tight. Turbidity of seawater was measured by using turbidimeters, namely bottles containing seawater samples which were stirred back and forth to prevent precipitation and were transferred into test tubes of 20-30 ml, and then placed into the turbidimeter and the results were recorded.

\subsection{Data collection of Environmental Chemical Factors}

Data collection of environmental chemical factors includes sa- linity, pH, Nitrate level, phosphate level, and dissolved oxygen. Measurement of salinity used refractometer, the measurement of sea $\mathrm{pH}$ used $\mathrm{pH}$ meter, and the measurement of dissolved oxygen used DO meter. The measurement of Nitrate and Phosphate level of sea water was done by spectrophotometer using DEREL 2800 spectrophotometer. The steps of measuring the Nitrate level were that $25-50 \mathrm{ml}$ water sample was filtered with Whatman filter paper no.42, and then it was piped as much as $5.0 \mathrm{ml}$ and put into the reaction tube and then added $0.5 \mathrm{ml}$ of Brucine and stirred and left for 2-4 minutes. After that, $5 \mathrm{ml}$ of concentrated Sulfuric Acid was added and stirred. Allowing it to cool down, and then measuring the Nitrate level with spectrophotometer at $420 \mathrm{~nm}$ wavelength. The steps of measuring the phosphate level of the seawater were that as

much as $25-50 \mathrm{ml}$ of seawater sample was filtered with a $0.45 \mu \mathrm{m}$ Millipore filter paper and then pipetted of $2.0 \mathrm{ml}$ and put into a test tube, $2.0 \mathrm{ml}$ of $\mathrm{H}_{3} \mathrm{BO}_{3} 1 \%$ was added and stirred. Next, $3.0 \mathrm{ml}$ of a phosphate oxidizing agent was added (mixture of $2.5 \mathrm{M}$ Sulfuric Acid, Askorbic Acid and Ammonium Molybdate), then left for one hour and the phosphate level was measured using a spectrophotometer at $640 \mathrm{~nm}$ wavelength.

\subsection{Data Collection of Macroalagae species}

The data collection of Macroalgae species was done by direct observation at four observation stations, and recording all the research variables in each observation plot by recording each species of macroalgae found in the observation plot. Once recorded, the examples of the macroalgae species found were then put into a sample plastic containing $4 \%$ formalin and labeled according to the station number, transect number, observation plot number, individual code, and date of capture.

\subsection{Data analysis}

The data obtained were analyzed descriptively to reveal the condition of the physicochemical environmental factors and macroalgae species in the coastal waters of Nusalaut, Central Maluku District, Indonesia.

\section{Results and Discussion}

\subsection{Condition of physicochemical environmental factors of the coastal water of Nusalaut}

The results of the measurement of physicochemical environmental factors of the coastal water of Nusalaut cover temperature, current strength, turbidity, salinity, $\mathrm{pH}$, Nitrate level, phosphate level and dissolved oxygen. The measurements were carried out on four different stations and the results were obtained as in table 1 below.

The results of temperature observation show that the higher the depth of the seawater, the lower the temperature is. This is due to the intensity of sunlight, in which the deeper the sea water, the more limited the penetration of the sunlight is, causing lower temperature (cold). Prasetyo and Suhendar [13] explained that sunlight is one of the determinants of sea water temperature. Furthermore, Hutabarat and Evans [14] state that the deeper the sea water, the less sunlight will be. Nontji [15] adds that in addition to sunlight, sea water temperature is also influenced by air temperature, air humidity, evaporation, and rainfall. The average temperatures found in all four research stations were still at a good temperature range for macroalgae growth. Atmaja [7] states that macroalgae found in 
Melsasail et al. | Sriwijaya Journal of Environemnt, 3 (1) 2018

Table 1. Mean of the Measurement Results of Physicochemical Factors in the coastal water of Nusalaut

\begin{tabular}{|c|c|c|c|c|c|c|c|c|}
\hline $\begin{array}{l}\text { Research } \\
\text { Station }\end{array}$ & $\begin{array}{l}\text { Tempera- } \\
\left.\text { ture }{ }^{\circ} \mathrm{C}\right)\end{array}$ & $\begin{array}{l}\text { Current } \\
\text { strength } \\
(\mathrm{cm} / \mathrm{s})\end{array}$ & $\begin{array}{c}\text { Turbidity } \\
\text { (mg/L) }\end{array}$ & 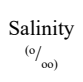 & $\mathrm{PH}$ & $\begin{array}{l}\text { Nitrate } \\
\text { level }{ }^{(\%}{ }_{\text {oo }}\end{array}$ & $\begin{array}{l}\text { Phosphate } \\
\text { level }{ }^{(\%}{ }_{\text {oo })}\end{array}$ & $\begin{array}{c}\text { Dissolved } \\
\text { oxygen } \\
(\mathrm{mg} / \mathrm{L})\end{array}$ \\
\hline $\begin{array}{l}\text { Amet Vil- } \\
\text { lage (I) }\end{array}$ & 29.25 & 29.95 & 9.9 & 32.25 & 7.92 & 2.9 & 0.85 & 2.93 \\
\hline $\begin{array}{c}\text { Nalahia } \\
\text { Village } \\
\text { (II) }\end{array}$ & 28.42 & 20.95 & 25.05 & 27.3 & 7.9 & 0.57 & 0.8 & 2.76 \\
\hline $\begin{array}{l}\text { Sila } \\
\text { Village } \\
\text { (III) }\end{array}$ & 28.5 & 15.3 & 27.31 & 26.3 & 6.92 & 0.55 & 0.75 & 3.61 \\
\hline $\begin{array}{l}\text { Leinitu } \\
\text { village } \\
\text { (IV) }\end{array}$ & 29.6 & 28.4 & 9.65 & 31.6 & 7.8 & 3.1 & 0.81 & 2.91 \\
\hline $\begin{array}{l}\text { Average } \\
\text { value }\end{array}$ & 28.94 & 23.65 & 17.98 & 29.36 & 7.63 & 1.78 & 0.8 & 3.05 \\
\hline
\end{tabular}

tropical climates can grow well at a temperature of $20-30^{\circ} \mathrm{C}$. Lower temperatures will cause the biochemical activity in the thallus to stop, and the membrane proteins and fats can suffer damages as a result of the formation of crystals in cells. Conversely, too high temperature would cause the destruction of biochemical mechanisms in the thallus [16].

Table 1 shows that the current strength at Station I (Amet Village) is higher than that in other observation stations, while the lowest current is at Station III (Sila Village). In general, the deeper the waters, the greater the current strength in the waters. Another factor that influences the current strength is the presence of seagrass beds. In shallow waters are overgrown with seagrass that can inhibit the current strength, whereas in deep seawater are rarely found seagrasses, so that the current strength is bigger because nothing holds the current strength. The results of the measurements of the current strength on each station were different because of the different depth of the waters, in which Station I and Station IV had deep waters, while Station II and III had shallow waters covered with seagrass beds. This is in accordance with the opinion by Nainggolan [17], that the strngth of currents in a waters is affected by the presence of sea grass and the depth of the waters. According to Rais [18], the range of the current strength of sea water which is suitable for the growth of macroalgae is $20-40 \mathrm{~cm} / \mathrm{sec}$. Therefore, the current strength in Station I, II and IV is included as strong current waters which is suitable for the growth of macroalgae. The weak current will inhibit the absorption of nutrients in macroalgae. In addition, mosses and microalgae inhibitants will also easily attach to the body of macroalgae. In contrast, too strong currents will disarm, bend and twist thallus of macroalgae that may damage the body of macroalgae [8].

The comparison of the measurment of the physicochemical factors in the four measuring stations in the coastal waters of Nusalaut Island of Central Maluku District can be seen in the following graph:

The measurement results of the turbidity of waters from the four stations showed varying results. The highest turbidity was at Station III, while the lowest turbidity was at Station I and IV. Related to the different depth of the waters at each measuring station, the deeper the seawater, the more the turbidity of the water. This is because the deeper the sea water, the faster the decomposition process of the particles carried by the river flow. Besides, the dirty water due to a lot of garbage causes high turbidity. Yusuf [19] states that turbidity of seawater is greatly influenced by several factors, namely the presence of colloidal particles and the suspense of inorganic

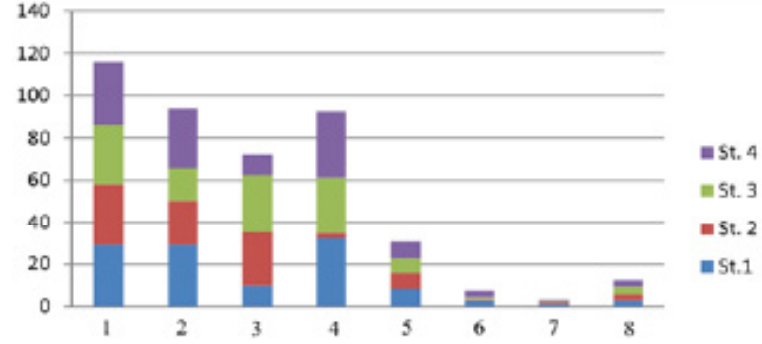

Figure 1. The comparison of ochemical factors at the four observation stations (Note: emperature, $2=$ Current strength, $3=$ Turbidity, $4=$ Salinity, $5=\mathrm{pH}$, $6=$ Nitrate level, $7=$ Phosphate Level,

\section{9=Dissolved oxygen}

materials which slowly decompose, as well as domestic waste contained in the waters. Armita [20] also adds that turbidity may cause habitat disturbance, respiratory distress, and lower oxygen levels in water. Walhi [21] states that a good range of turbidity for the growth of macroalgae is $0-20 \mathrm{mg} / \mathrm{L}$. Thus, Station I and IV were had good turbidity for the macroalgae growth, while Station II and III had not good turbidity for macrolaga growth because of its high turbidity. This is in accordance with the opinion of Effendi [9] who states that too high turbidity will inhibit the penetration process of sunlight into the water.

Similar to the turbidity, the measurements of the salinity of the sea water indicate that Station I and IV have higher salinity level than that at Stations II and III. This is because the waters at Station I and IV is deeper that that at Station II and III. The deeper the waters the more the mixing process of the water at each research station with the mass of the open sea water (Banda Sea and the Seram Sea). Another factor that causes the low salinity in Station II and III is the presence of river mouths, whereas in Station I and IV there is no river mouth. This is in accordance with the opinion of Prasetya and Suhendar [13] who state that the salinity of sea water is influenced the number of rivers which run into the sea. Nyabakken [22] also suggests that the salinity of waters is also affected by topography, season, tides, and rainfall. Kadi [23] suggests that the range of salinity which is good for the growth of macroalgae is 32$34 \%$ Based on that, the salinity of Station I and IV supports the presence and the growth of macroalgae.

The average $\mathrm{pH}$ at Station I, II, and IV is almost similar, that is in the range of neutral or almost alkaline, whereas at Station III the $\mathrm{pH}$ is in the range of acid or almost neutral. This difference occurs because the waters at the station I, II, and IV were cleaner from rubbish than that at Station III. Yusuf [19] states that the activity of phytoplankton and other aquatic plants in the use of $\mathrm{CO}_{2}$ during photosynthesis are the factors causing the change of seawater $\mathrm{pH}$. Ruslan [24] also suggests that changes in sea water to become acidic are due to the increase of organic materials in the waters which liberates $\mathrm{CO}_{2}$ if the decomposition process occurs. Sirajudin [25 suggests that the $\mathrm{pH}$ of seawater which is suitable for the growth of macrolgae is between 7-9. Low $\mathrm{pH}$ will suppress the growth rate of macroalgae, and even the acidity level can be deadly, and there will not be any reproduction rate in macroalgae.

The results of the measurement of Nitrate concentration in table 1 show that the average of nitrate in Station I and IV is higher than that at Station II and III. This difference is most likely caused by the presence of more garbage at stations II and III, both domestic waste and the waste from the State Electricity Company (PLN). Marganof [26] states that the concentration of Nitrate in waters is 
affected by the mixing of sea water and garbage originating from domestic, agricultural and industrial waste. According to Putinella [27], the range of Nitrate which is good for the growth of macroalgae is 0.9 to $3.5 \%$ o. Based on the criteria, Station I and station IV have a good Nitrate level for the macroalgae growth, while Station II and III have Nitrate levels which are not quite good for the presence and growth of macroalgae. Low level of nitrate can inhibit the metabolism and reproduction of macroalgae [9].

The results of the measurement of Phosphate level on four measuring stations according to table 1 show that the average phosphate level at Station I, II, and IV is in the range of 0.8, and the phosphate level at Station III is lower at 0.7. Phosphate levels are indirectly influenced by the strength of water currents. Station I, II and IV have relatively strong currents that cause relatively large water mass mixing, so that phosphate level is lifted from the base to the surface of the sea. This is inversely proportional to Station III which has a weaker current which causes only a little amount of phosphate uplifted. Simanjuntak [28], states that the high level of phosphates in a waters is strongly influenced by currents that cause the lifting of phosphate to the surface. He further adds that the range of Phosphate which is good for the growth of macroalgae is 0.10 to $1.68 \%$ Thus, the phosphate level at Stations I, II and IV is almost close to the criteria of phosphate level that is good for macroalgae growth.

The average of dissolved oxygen at all four stations indicates that there was a difference. The average dissolved oxygen at station III was $3.61 \mathrm{mg} / \mathrm{L}$, at station I was $2.93 \mathrm{mg} / \mathrm{L}$, and at station IV was $2.91 \mathrm{mg} / \mathrm{L}$, and at station II was $2.76 \mathrm{mg} / \mathrm{L}$. The difference is caused that in Station III there were more seagrasses than macroalga, so that photosynthesis process was better, consequently the dissolved oxygen was higher. This is inversely proportional to Station I, II and IV which had a large number of macroalgae species, but the number of seagrass was small, so that the dissolved oxygen was low. Effendi [9] states that the activity of photosynthesis by aquatic plants and phytoplankton is the source of dissolved oxygen in the waters. According to Yusuf [19], the range of dissolved Oxygen for the macroalgae growth is $2.0-3.5 \mathrm{mg} / \mathrm{L}$. Thus Station I, II and IV have a good level of dissolved oxygen for the grwoth of macrolagae, whereas at Station III the dissolved oxygen level has slightly exceeded the optimum range for the macrolagae growth.

From the results and discussion of the physicochemical factors of the coastal waters of Nusalaut Island, it can be said that the best potential of the presence and macroalgae growth is at Station I (Amet Village) and at Station IV (Leinitu Village). This can be seen from all the physicochemical factors measured which indicates that Station I and IV always meet the criteria as a good habitat for macroalgae.

\subsection{Macroalgae species in the coastal waters of Nusalaut Island in Central Maluku}

The results of observations on the four research stations obtained some species of macroalgae which are presented in table 2 below.

Table 2. shows that there are 17 species of macroalgae found in the Coastal waters of Nusalaut in Central Maluku District. At station I (Amet Village), 15 species of macroalgae are found consisting of 5 species of green algae (Chlorophyceae), two species of brown algae (Phaeophyceae), and 8 species of red algae (Rhodophyceae). At the station II (Nalahia Village), six species of macroalgae are found consisting of 1 species of green algae (Chlorophyceae) and 5 species of red algae (Rhodophyceae), while brown algae is not found (Phaeophyceae). At the third station (Sila Village) 4 spe-
Table 2. Macroalgae Species Found in the coastal waters of Nusalaut

\begin{tabular}{llcccc}
\hline \multirow{2}{*}{ No. } & \multirow{2}{*}{ Macroalgae Species } & \multicolumn{4}{c}{ Research sites } \\
\cline { 2 - 6 } & & Station I & Station II Station III Station IV \\
\hline 1 & Caulerpa serrulata & $\sqrt{ }$ & - & - & - \\
2 & Codium decorticatum & $\sqrt{ }$ & $\sqrt{ }$ & - & $\sqrt{ }$ \\
3 & Dictyosphaeria cavernosa & $\sqrt{ }$ & - & - & - \\
4 & Halimeda opuntia & $\sqrt{ }$ & - & $\sqrt{ }$ & - \\
5 & Neomeris annulata & $\sqrt{ }$ & - & - & - \\
6 & Dictyosphaeria acrostichoides & - & - & - & $\sqrt{ }$ \\
7 & Padina Australis & $\sqrt{ }$ & - & $\sqrt{ }$ & - \\
8 & Sargassum cincitum & $\sqrt{ }$ & - & - & - \\
9 & Acantophora dendroides & $\sqrt{ }$ & - & - & - \\
10 & Acantophora specivera & $\sqrt{ }$ & $\sqrt{ }$ & - & $\sqrt{ }$ \\
11 & Galaxaura subfruticolosa & $\sqrt{ }$ & - & - & - \\
12 & Gracilaria corticata & $\sqrt{ }$ & - & - & $\sqrt{ }$ \\
13 & Gracilaria dura & $\sqrt{ }$ & $\sqrt{ }$ & - & $\sqrt{ }$ \\
14 & Gracilaria salicornia & $\sqrt{ }$ & $\sqrt{ }$ & $\sqrt{ }$ & $\sqrt{ }$ \\
15 & Hypnea valentiae & $\sqrt{ }$ & $\sqrt{ }$ & $\sqrt{ }$ & $\sqrt{ }$ \\
16 & Laurencia papilosa & $\sqrt{ }$ & - & - & - \\
17 & Liagora viscida & - & $\sqrt{ }$ & - & $\sqrt{ }$ \\
\hline \multicolumn{7}{l}{ Number of Species } & 15 & 6 & 4 & 8 \\
\hline
\end{tabular}

cies of macroalgae are found consisting of 1 species of green algae (Chlorophyceae), 1 species of brown algae (Phaeophyceae) and 2 species of red algae (Rhodophyceae). At the fourth station (Leinitu Village) 8 species of macroalgae are found consisting of 1 species of green algae (Chlorophyceae), one species of brown algae (Phaeophyceae), and 6 species of red algae (Rhodophyceae). Overall, the most groups of macroalgae which are found in the coastal waters of Nusalaut Island in Maluku district are of the Rhodophyceae class (red algae), followed by the Chlorophyceae class (green algae), while the fewest groups of macroalgae found are of the Phaeophyceae class (brown algae). According Diasz-Pulido \& McCook [29], macroalgae are a source of food for herbivorous marine and plays an important role in nitrogen fixation and has important contributions to the growth of coral skeleton by depositing calcium carbonate $\left(\mathrm{CaCO}_{3}\right.$

Almost all species of macroalgae found in the coastal waters of Nusalaut Island are always present in Station I, except the Dictyosphaeria acrostichoides species, which is only found in station IV, and Liagora viscida species which is only found in station II and IV. This is directly proportional to the results of the physicochemical factor measurement, in which Station I is the best place for the presence and the growth of macroalgae. However, if it is related to the previous research, it can be said that there has been a decrease in the number of macroalgae species in the coastal waters of Nusalaut Island, Central Maluku District. Based on the results of research by Papalia [30], 36 species of macroalgae were found in Nusalaut Island, Central Maluku District. However, this time, only 15 species of macrolaga e are found in the coastal waters of Nusalaut Island. This is most likely due to the anthropogenic activity and the increasing amount of waste in the waters resulting in the decreasing quality of coastal waters in Nusalaut Island, Central Maluku Districy, which has an impact on the presence and growth of each macroalgae species. According to Morand \& Merceron [31], if there is an excessive population increase only in one type of macroalgae in a waters, it means that the waters have experienced eutrophication. However, since in the coastal waters of Nusalaut Island are still found various species of macroalgae, it can be con- 


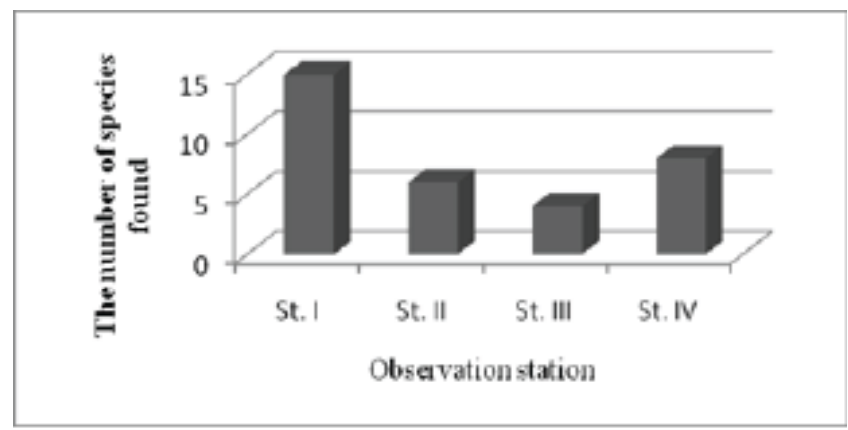

Figure 2. The comparison of the number of species found at each station

cluded that the coastal waters of Nusalaut Island does not experience eutrophication.

\section{Conclusion}

From the results and discussion of this research, it can be concluded that: 1) The physicochemical factors in the coastal waters of Nusalaut Island, Central Maluku District are slightly various, but they are generally still suitable for the presence and the growth of macroalgae. 2) In accordance with the condition of the physicochemical factors during the measurement, the most macrolagae species are found in Station I (Amet Village), followed by Station IV (Leinitu Village) and Station II (Nalahia Village), while the fewest macroalgae species are found in Station III (Sila Village). 3) The requirements of the presence and the growth of macroalgae species in the coastal waters of Nusalaut Island are that the temperature does not exceed $30^{\circ} \mathrm{C}$ and not less than $20^{\circ} \mathrm{C}$, the optimum current strength is $20-40 \mathrm{~m} / \mathrm{sec}$, the optimum turbidity is not more than $0-20 \mathrm{mg} / \mathrm{L}$, the optimum salinity is $32-34 \%$ the optimum $\mathrm{pH}$ is $7-9$, the optimum nitrate level is 0.9 to $3.5 \%$ oo, optimum phosphate level is 0.10 to $1.68 \%$ and a good level of dissolved oxygen is 2.0 to $3.5 \mathrm{mg} / \mathrm{L}$. 4) In general, 17 species of macrolgae are currenlty found consisting of the class of Rhodophyceae, Chlorophyceae and Phaeophyceae on the optimum physicochemical factor conditions in the coastal waters of Nusalaut Island, Central Maluku district.

\section{Acknowledgement}

The authors thank the Director of the College of Teacher Training and Education Science, Gotong Royong, Masohi (STKIP-Gotong Royong), which has provided scholarship assistance for the completion of this research in Biology Education Study Program, Postgraduate, Pattimura University, year 2014/2015.

\section{References}

[1] Wiryato, J. 2015. Beberapa jenis Makro Alga yang Ditemukan di Zona Pasang Surut Pantai Pandawa Badung Bali [Some species of macroalgae found in Tidal Zone of Pandawa Badung Bali Beach]. Fakultas Matematika dan Ilmu Pegetahuan Alam Jurusan Biologi Universitas Udayana: Bukit Jimbaran, Bali. [In Indonesian].

[2]Fachrul, M. 2007. Metode Sampling Bioekologi [Bioecology Sampling Method]. Jakarta: Bumi Aksara. [In Indonesian].

[3]Namakule, U., Rehena, J.F., \& Rumahlatu, D. 2017. Seagrass community structure in various zones in coastal waters of
Haya village, Central Moluccas district, Indonesia. $A A C L$ Bioflux 10(15): 1226-1237.

[4]Anggadireja, J.T., Zantika, A., Purwoto, H., \& Istini, S. 2006. Rumput Laut [Seaweed]. Jakarta: Penebar Swadaya. [In Indonesian].

[5]Rumahlatu, D., \& Leiwakabessy, F. 2017. Biodiversity of gastropoda in the coastal waters of Ambon Island, Indonesia. AACL Bioflux 10(2): 285-296.

[6]Latupono, B., Leiwakabessy, F., \& Rumahlatu, D. 2017. Biodiversity of Echinodermata in Marsegu Island. Sriwijaya Journal of Environment 2(3): 81-87.

[7]Atmaja, W.S. 2007. Pengenalan Jenis Alga Cokelat [Introducing Brown Algae Species].in introducing seaweed species. Puslitbang Oseanologi LIPI-Jakarta. [In Indonesian].

[8]Junaedi, W. 2004. Rumput Laut. Jenis dan Morfologinya [Seaweed. The species and the morphology]. Departemen Pendidikan Nasional. Direktorat Jenderal pendidikan Dasar dan Menengah. Direktorat Pendidikan Menengah Kejuruan. [In Indonesian].

[9]Efendi. 2003. Telaah Kualitas Air bagi Pengelolaan Sumberdaya dan Lingkungan Perairan [Assessing Water Quality for Water Resources and Environmental Management]. Yogyakarta: Kanisius. [In Indonesian].

[10]Ambas. 2006. Potensi Pemanfaatan dan Prospek Pengembangan Budidaya Rumput Laut di Indonesia [the potential of Utilizing and the Prospects of Developing Seaweed Cultivation in Indonesia]. Badan Pengembangan Ekspor Nasional. Departeman Perdagangan dan Koperasi, Jakarta. 13 hal. [In Indonesian].

[11]Tim Peneliti Sumber Daya Pesisir Pulau Nusalaut. 2009. Survei Inventarisasi Sumber Daya Wilayah Pesisir Pulau Nusalaut dan Sekitarnya Kabupaten Maluku Tengah [Survey of Coastal Resource Inventory in Nusalaut Island Central Maluku]. Puslitbang Oseanologi-LIPI. Ambon. [In Indonesian].

[12]Papalia, S., \& Arfah, H. 2009. Produktivitas Biomassa Makro Alga di Perairan Pulau Nusalaut Maluku Tengah [Productivity of Macro Algae -Biomass in Nusalaut Island Waters of Central Maluku]. Jurnal Ilmu dan Teknologi Kelautan Tropis 5(2): 465-477. [In Indonesian].

[13]Prasetyarto \& Suhendar. 2010. Modul Tentang Laut dan Pesisir [Modules of Sea and Coastal area]. Jakarta. [In Indonesian].

[14]Hutabarat, S., \& Evans, S.M. 2001. Pengantar Oseanografi [Introduction to Oceanography]. Universitas Indonesia: Jakarta. [In Indonesian].

[15]Nontji, A. 2002. Laut Nusantara [The Archipelago Sea]. Jakarta: Djambatan. [In Indonesian].

[16] Lunning, K. 1990. Seaweed Their Environment, Biogeography and Ecophysiology. John Willey and Sons, Inc. 527 hal.

[17] Nainggolan, P. 2011. Distribusi Spasial dan Pengelolaan Lamun (Seagrass) di Teluk Bakau, Kepulauan Riau [Spatial Distribution and Seagrass Management in Teluk Bakau, Riau Islands]. [Essay Institut Pertanian Bogor, Bogor. 95 hal. [In Indonesian]

[18] Rais, H. 2008. Budidaya Rumput laut dan Kemungkinan Pengembangannya di provinsi Maluku [Seaweed Cultivation and Its Possible Development in Maluku province]. WBL/85/ WP-31. [In Indonesian].

[19] Yusuf, M.I. 2005. Laju Pertumbuhan Harian, Produksi dan Kualitas Rumput Laut Kappaphycus alvarezii (Doty),1988 yang Dibudidayakan Dengan Sistem Aliran Air Media dan Tallus Benih yang Berbeda [Daily Growth, Production and 
Quality of Kappaphycus alvarezii Seaweed (Doty), 1988 Cultivated With Air Flow Systems Media and Different Tallus Seed. Universitas Hasanudin. Makassar. [In Indonesian].

[20] Armita, D. 2011. Analisis Perbandingan Kualitas Air di Daerah Budidaya Rumput Lut Dengan daerah Tidak Ada Budidaya Rumput Laut, di Dusun Malelaya Desa Punaga Kecamatan Mangarabombang Kabupaten Takalar [Comparative Analysis of Water Quality in SeaGrass Aquaculture region and non - seagrass aquaculture region, in Malelaya Hamlet Punaga Village Mangarabombang District, Takalar]. Universitas Hasanudin: Makassar. [In Indonesian].

[21] Walhi. 2006. Dampak Lingkungan Hidup Operasi Pertambangan Tembaga dan Emas Freeport-Rio Tinto di Papua [Environmental Impact of Copper and Gold Mining and Freeport-Rio Tinto in Papua]. WALHI: Jakarta-Indonesia. [In Indonesian].

[22] Nyabakken, J.W. 2000. Biologi Laut Suatu Pendekatan Ekologi [Marine Biology An Ecological Approach]. Jakarta: PT. Gramedia. [In Indonesian].

[23] Kadi, A. 2006. Kondisi Habitat dan Komunitas Makro Alga di Perairan Pulau Simeuleu-Aceh Barat Paska Tsunami [The conditions of the Habitat and Algae Macro Communities in Simeuleu- West Aceh After Tsunami]. Oseanologi dan Limnologi di Indonesia 33: 427-439. [In Indonesian].

[24]Ruslan, M. 2002. Studi Beberapa Parameter Fisika-Kimia Air di Perairan Danau Tempe Kabupaten Wajo [Study of Multiple Parameter of Physico-Chemical Water in the waters of Lake Tempe Wajo]. Universitas Hasanudin: Makassar. [In Indonesian].

[25]Sirajudin, M. 2009. Analisa Ruang Ekologi untuk Pengelompokkan Zona Pengembangan Budidaya Rumput Laut (Euchema cottoni) di Teluk Waworanda Kabupaten Bima [Ecology Space Analysis for Grouping Seaweed Development Zones (Euchema cottoni) in the Waworanda Gulf, Bima Regency]. Thesis Unpublished. Bogor: Program Pascasarjana, IPB. [In
Indonesian].

[26]Marganof. 2007. Model Pengendalian Pencemaran Perairan di Danau Maninjau Sumatera Barat [Water Pollution Control Model in Lake Maninjau West Sumatra]. [Dissertation]. Sekolah Pasca Sarjana, Institut Pertanian Bogor,135 Hlm. [In Indonesian].

[27]Putinella, J.D. 2001. Evaluasi Lingkungan Budidaya Rumput Laut di Teluk Baguala, Maluku [Evaluation of Seaweed Cultivation Environment in the Baguala Gulf, Maluku]. (Research proposal). Program Pascasarjana, UGM: Yogyakarta, 7 halaman. [In Indonesian].

[28]Simanjuntak, M. 2006. Kadar Fosfat, Nitrat, dan Silikat Kaitannya Dengan Kesuburan di Perairan Delta Mahakam, Kalimatan Timur [Levels of Phosphate, Nitrate, and Silicate on the Relation with Fertility in the waters of Delta Mahakam, East Kalimantan]. Pusat Penelitian Oseanografi LIPPI: Jakarta. [In Indonesian].

[29]Diaz-Pulido, G., McCook, L.J. 2008. Environmental Status: Macroalgae (Seaweeds). A, (ed) The State of the Great Barrier Reef On-line, Great Barrier Reef Marine Park Authority, Townsville. Viewed on (enter date viewed), http://www. gbrmpa.gov.au/corp site/info services/publications/sotr/ downloads/SORR_Macr oalgae.pdf

[30]Papalia, S., Arfah, H., Irianto, B., \& Pattipeilohy, F. 2009. Distribusi dan Keragaman Jenis Makroalga di Perairan Pulau Nusalaut Maluku Tengah [Distribution and Diversity of Macroalgae Species in Nusalaut Island Waters of Central Maluku]. Jurnal Perairan Maluku dan Sekitarnya 4: 73-79.

[31]Morand, P., \& Merceron, M. 2005. Macroalgal Population and Sustainability. Jornal of Coastal Research 21(5): 1009 1020 . 